\title{
PERAN PEMBIAYAAN MUDHARABAH TERHADAP PENERIMAAN KAS PADA BMT KI AGENG PANDANARAN SEMARANG
}

\author{
Muhammad Ali Ridho \\ Diploma Akuntansi Fakultas Ekonomi Universitas Islam Sultan Agung Semarang \\ ridho.yiaspfm@gmail.com
}

\begin{abstract}
$T$ The purpose of this paper is to determine the role of financing Mudharabah of cash receipts on BMT Ki Ageng Pandanaran Semarang. Cash receipts on the BMT Ki Ageng Pandanaran Semarang is obtained from several sources, one of which is derived from the shared revenues of financing. Type of financing discussed in this article is financing Mudharabah which is the primary financing in the syari'a financial institutions. This study uses qualitative methods with interview approach to the parties involved in financing Mudharabah and cash receipts. Analysis of the data from the result of the interviews will be discussed with descriptive methods. This study is expected to provide solutions to the problems of cash receipts at BMT Ki Ageng Pandanaran Semarang, especially on the financing Mudharabah.
\end{abstract}

Keywords: Financing Mudharabah, Cash Receipts, BMT Ki Ageng Pandanaran Semarang

\begin{abstract}
Abstrak
$\mathrm{T}$ ujuan penulisan ini untuk mengetahui peran pembiayaan mudharabah terhadap penerimaan kas pada BMT Ki Ageng Pandanaran Semarang. Penerimaan kas pada BMT Ki Ageng Pandanaran Semarang diperoleh dari beberapa sumber, salah satunya berasal dari pendapatan bagi hasil pembiayaan. Jenis pembiayaan yang dibahas pada tulisan ini adalah pembiayaan mudharabah yang merupakan pembiayaan primer dalam lembaga keuangan syari'ah. Penelitian ini menggunakan metode kualitatif dengan pendekatan wawancara dengan pihak-pihak yang terkait pembiayaan mudharabah dan penerimaan kas. Analisis data dari hasil wawancara kemudian dibahas dengan metode deskriptif. Penelitian ini diharapkan memberikan solusi terhadap permasalahan penerimaan kas pada BMT Ki Ageng Pandanaran Semarang khusus pada pembiayaan mudarabah.
\end{abstract}

Kata Kunci: Pembiayaan Mudharabah, Penerimaan Kas, BMT Ki Ageng Pandanaran Semarang

\section{PENDAHULUAN}

Perbankan syari'ah merupakan sebuah sistem perbankan yang pelaksanaanya berdasarkan prinsip-prinsip syari'at Islam. Dalam pelaksanaanya, perbankan syari'ah berfungsi menghimpun dana dari masyarakat dalam bentuk simpanan dan manyalurkannya dalam bentuk pembiayaan. Di Indonesia, lembaga keuangan syari' ah yang pertama kali berdiri adalah Bank Muamalat Indonesia (BMI). Seiring berjalannya waktu, lembaga keuangan syari'ah semakin berkembang. Hal ini ditandai dengan munculnya berbagai bank Islam di Indonesia, salah satunya adalah BMT. 
BMT merupakan kependekan dari Baitul Mal wat Tamwil.Secara harfiah, bait al-mal mengandung arti rumah uang dan bait at-tamwil artinya rumah pembiayaan. Dari pengertian tersebut, dapat diartikan bahwa BMT merupakan sebuah lembaga keuangan mikro yang mana menghimpun dana dari masyarakat, lalu menyalurkannya kembali kepada masyarakat. Salah satu produk BMT adalah pembiayaan.

Jenis pembiayaan yang sering digunakan BMT adalah pembiayaan mudharabah dan musyarakah. Pembiayaan mudharabah merupakan pembiayaan primer yang ada dalam lembaga keuangan syari'ah. Pembiayaan mudharabah adalah sebuah layanan yang diberikan BMT sebagai bentuk penyaluran dana kepada masyarakat. Sistem yang digunakan dalam pembiayaan mudharabah menggunakan sistem bagi hasil, yang mana keuntungannya dibagi kepada kedua belah pihak sesuai nisbah yang telah disepakati. Dengan demikian, dalam pembiayaan mudharabah ada sebuah keuntungan yang akan diperoleh pihak BMT. Keuntungan tersebut akan berpengaruh terhadap penerimaan kas BMT.

Penerimaan kas merupakan salah hal yang penting bagi sebuah perusahaan, bagitu juga dengan BMT. Sebagai sebuah organisasi, BMT pasti mempunyai visi, misi, maupun tujuan yang ingin dicapai. Kas merupakan salah satu faktor penting untuk mencapai visi, misi maupun tujuan BMT. BMT harus memaksimalkan sumber penerimaan kas yang dimiliki agar dapat mencapai visi, misi, dan tujuan yang diinginkan. Pendapatan bagi hasil pembiayaan merupakan salah satu sumber penerimaan kas bagi BMT. Hal ini harus dimaksimalkan oleh BMT.

Uraian diatas menjelaskan bahwa pembiyaan mudharabah harus tetap dipertahankan bahkan harus ditingkatkan untuk meningkatkan sumber penerimaan kas pada BMT. Pembiayaan mudharabah merupakan jenis pembiayaan utama dalam produk pembiayaan Islam. Diharapkan pembiayaan mudharabah tersebut dapat meningkat dari tahun ke tahun dan peminatnya semakin banyak agar sumber penerimaan kas dari BMT juga bisa semakin meningkat.

Tujuan penelitian ini adalah untuk menginvestigasi kegiatan pembiayaan mudharabah dan penerimaan kas. Selain itu juga bertujuan untuk mengetahui bagaimana peranan pembiayaan mudharabah terhadap penerimaan kas di BMT. Penelitian ini dilaporkan sebagai hasil kegiatan magang selama satu bulan di BMT Ki Ageng Pandanaran Semarang. BMT tersebut menjadi objek penelitian dalam penelitian ini dan mungkin bisa memberikan gambaran umum terhadap kondisi BMT lainnya di Indonesia.

\section{TINJAUAN PUSTAKA}

\section{Sistem Pengendalian Intern Penerimaan Kas}

Sistem pengendalian intern menurut Mulyadi adalah gabungan suatu sistem yang meliputi struktur organisasi, metode dan ukuran-ukuran yang dikoordinasikan untuk menjaga kekayaan organisasi, mengecek ketelitian dan keandalan data akuntansi, mendorong efisiensi dan mendorong dipatuhinya kebijakan manajemen. ${ }^{1}$ Sedangkan menurut Krissmiaji, pengendalian intern (intern control) adalah pengendalian yang bertujuan membantu menjaga aktiva dan menjamin akurasi dan daya andal catatan keuangan perusahaan".2

Kas merupakan alat pertukaran yang dipergunakan sebagai ukuran dalam akuntansi sehingga menggambarkan kondisi likuiditas perusahaan. Selain itu kas merupakan golongan aktiva lancar yang paling likuid dan sangat penting karena menggambarkan daya beli umum dan dapat memproses barang dan jasa. Mulyadi menyatakan bahwa penerimaan kas perusahaan berasal dari dua sumber utama yaitu penerimaan kas dari penjualan tunai dan penerimaan kas dari piutang. ${ }^{3}$ Selain itu, Mulyadi juga menyatakan bahwa penerimaan kas dari piutang dapat dilakukan melalui berbagai cara: (1) Penagihan perusahaan, (2) Pos, dan(3) Lock-bock

1 Mulyadi. Sistem Akuntansi. Salemba Empat: Jakarta. 2001. Hal. 163

2 Krismiaji. Sistem Informasi Akuntansi. Yogyakarta: UPP AMP YKPN. 2005. Hal. 218

$3 \quad$ Mulyadi, Op. Cit. hal. 482 
collection plan. ${ }^{4}$ Sedangkan sistem penerimaan kas penjualan tunai merupakan sistem yang dilaksanakan oleh perusahaan dengan cara mewajibkan pembeli melakukan pembayaran harga barang terlebih dahulu sebelum barang diserahkan oleh perusahaan kepada pembeli. Setelah uang muka diterima oleh perusahaan, barang kemudian diserahkan kepada pembeli dan transaksi penjualan tunai kemudian dicatat oleh perusahaan. ${ }^{5}$

Menurut Mulyadi, sistem pengendalian intern penerimaan kas adalah suatu catatan yang dibuat untuk melaksanakan kegiatan penerimaan uang dan penjualan tunai atau dari piutang yang siap dan bebas digunakan untuk kegiatan umum perusahaan". ${ }^{6}$ Dari pengertian di atas dapat disimpulkan bahwa sistem pengendalian intern penerimaan kas yaitu suatu jaringan prosedur yang menangani suatu peristiwa atau kejadian yang mengakibatkan terjadinya penambahan uang dalam kas yang berasal dari penjualan tunai maupun piutang yang melibatkan bagian-bagian yang saling berkaitan satu sama lain.

\section{Sistem Penerimaan Kas dari Piutang}

Sistem penerimaan kas dari piutang merupakan serangkaian kegiatan bisnis yang terjadi secara berulang dan kegiatan pengolahan informasi yang berhubungan dengan penyerahan barang dan jasa kepada pelanggan dan penerimaan penyerahan kas dari penyerahan barang dan jasa yang dijual secara kredit kepada pelanggan. Penerimaan kas dari piutang dapat dilakukan melalui berbagai cara ; (1) Penagihan perusahaan, (2) Pos, (3) Lock-bock collection plan. ${ }^{7}$

Prosedur yang membentuk sistem penerimaan kas dari piutang adalah sebagai berikut; pertama, prosedur penerimaan kas dari piutang melalui penagihan perusahaan, yang meliputi; (1) Bagian piutang memberikan daftar piutang yang sudah saatnya ditagih kepada bagian penagih, (2) Bagian penagihan mengirimkan penagih yang merupakan karyawan perusahaan untuk melakukan penagihan kepada debitur, (3) Bagian penagihan menerima cek atas nama dan surat pemberitahuan dari debitur, (4) Bagian penagihan menyerahkan cek kepada bagian kasa, (5) Bagian penagihan menyerahkan surat pemberitahuan kepada bagian piutang untuk kepentingan posting ke dalam kartu piutang, (6) Bagian kasa mengirim kwitansi sebagai tanda penerimaan kas kepada debitur, (7) Bagian kasa menyetorkan cek ke bank, setelah cek atas cek tersebut dilakukan endorsement oleh pejabat yang berwenang, dan (8) Bank perusahaan melakukan clearing atas cek tersebut ke bank debitur.

Prosedur yang kedua yaitu penerimaan kas dari piutang melalui pos, yang meliputi; (1) Bagian penagihan mengirim faktur penjualan kredit kepada debitur pada saat transaksi penjualan kredit tersebut, (2) Debitur mengirim cek atas nama yang dilampiri surat pemberitahuan melalui pos, (3) Bagian sekretariat menerima cek atas nama dan surat pemberitahuan dari debitur, (4) Bagian sekretariat menyerahkan surat pemberitahuan kepada bagian piutang untuk kepentingan posting kedalam kartu piutang, (5) Bagian kasa mengirim kwitansi kepada debitur sebagai tanda terima pembayaran, (6) Bagian kasa menyetorkan cek ke bank setelah cek tersebut dilakukan endorsement oleh pejabat yang berwenang, dan (7) Bank perusahaan melakukan clearing atas cek tersebut ke bank debitur.

Prosedur yang ketiga yaitu penerimaan kas dari piutang melalui lock-bok-collection plan, yang meliputi; (1) Bagian penagihan mengirim faktur penjualan kredit kepada debitur pada saat transaksi terjadi, (2) Debitur melakukan pembayaran uangnya pada saat faktur jatuh tempo dengan mengirimkan cek dan surat pemberitahuan ke PO BOX di kota terdekat, (3) Bank membuka PO BOX dan mengumpulkan cek dan surat pemberitahuan yang diterima oleh perusahaan, (4) Bank membuat daftar surat pemberitahuan, (5) Bank mengurus check
Ibid
Ibid, hal. 455
Ibid. Hal. 500
Ibid, hal. 482 
clearing, (6) Bagian sekretariat menyerahkan surat pemberitahuan kepada bagian piutang untk mengkredit rekening pembantu piutang dari debitur yang bersangkutan, (7) Bagian sekretariat menyerahkan surat pemberitahuan ke bagian kasa, dan (8) Bagian kas menyerahkan daftar surat pemberitahuan ke bagian jurnal untuk mencatat dalam jurnal penerimaan kas.

\section{Sistem Penerimaan Kas dari Penjualan Tunai}

Menurut Mulyadi sistem penerimaan kas penjualan tunai merupakan sistem yang dilaksanakan oleh perusahaan dengan cara mewajibkan pembeli melakukan pembayaran harga barang lebih dahulu sebelum barang diserahkan oleh perusahaan kepada pembeli. Setelah uang muka diterima oleh perusahaan, barang kemudian diserahkan kepada pembeli dan transaksi penjualan tunai kemudian dicatat oleh perusahaan. ${ }^{8}$

Nugroho Wijayanto menyatakan bahwa sistem penerimaan kas penjualan tunai merupakan siklus akuntansi yang melibatkan bagian-bagian seperti pencatatan nota, pengendalian intern, perekapan hasil penjualan dan laporan yang menghasilkan informasi penjualan dengan pembayaran secara langsung menggunakan uang tunai dalam mengambil keputusan". ${ }^{9}$ Dengan demikian dari pengertian di atas dapat disimpulkan bahwa penjualan tunai merupakan penjualan dengan mengambil dari supplier dan langsung dikirim ke pelanggan secara pembayaran langsung dengan menggunakan uang tunai dan dengan harapan akan mendapatkan laba dari kegiatan penjualan tersebut.

\section{Fungsi Yang Terkait Penerimaan Kas}

Untuk menjual produk dan jasa yang dihasilkan perusahaan kepada pelanggan diperlukan fungsi-fungsi yang merupakan bagian dari daur pendapatan. Daur pendapatan merupakan ujung tombak aktivitas perusahaan yang akan menghasilkan nutrisi bagi perusahaan dalam bentuk pendapatan hasil penjualan. ${ }^{10}$

Menurut Mulyadi, fungsi yang terkait penerimaan kas adalah $;^{11}$

a. Fungsi Penjualan. Fungsi ini bertanggung jawab untuk menerima order dari pembeli, mengisi faktur penjualan tunai, dan menyerahkan faktur tersebut kepada pembeli untuk kepentingan pembayaran harga barang ke fungsi kas.

b. Fungsi Kas. Fungsi ini bertanggung jawab sebagai penerima kas dari pembeli.

c. Fungsi Gudang. Fungsi ini bertanggung jawab untuk membungkus barang dan menyerahkan barang yang dipesan pembeli, serta menyerahkan barang tersebut ke fungsi pengiriman.

d. Fungsi Pengiriman. Fungsi ini bertanggung jawab untuk membungkus barang dan menyerahkan barang yang telah dibayarkan harganya kepada pembeli.

e. Fungsi Akuntansi. Fungsi ini bertanggung jawab sebagai pencatatan transaksi penjualan dan penerimaan kas dan pembuatan laporan penjualan.

\section{Dokumen yang Terkait Penerimaan Kas}

Dokumen dan catatan sistem penerimaan kas harus didukung dengan dokumen bisnis yang menunjukkan bukti penjualan secara tertulis. ${ }^{12}$ Dokumen merupakan formulir khusus yang digunakan untuk mencatat data tentang aktivitas bisnis untuk pengawasan dan pengendalian serta akurasi yang lebih baik. ${ }^{13}$ Dokumen yang terkait sistem penerimaan kas; ${ }^{14}$

$8 \quad$ Ibid, hal. 455

9 Nugroho Widjajanto, Sistem Informasi Akuntansi, Jakarta; Erlangga, 2001, hal. 137

10 Ibid, hal. 304

11 Mulyadi, Op. Cit., hal. 462

12 Jerry Weygandt J., dkk., Accounting Principles Edisi Ketujuh, Jakarta; Salemba Empat, 2007, hal. 267

13 Krismiaji, Sistem Informasi Akuntansi, Yogyakarta; UPP AMP YKPN, 2005, hal. 275

14 Mulyadi, Op. Cit., hal 463 
a. Faktur Penjualan Tunai. Menurut Krismiaji faktur penjualan berfungsi untuk merekam transaksi penjualan barang baik tunai maupun kredit. ${ }^{15}$ Dokumen ini digunakan untuk merekam berbagai informasi yang diperlukan oleh manajemen mengenai transaksi penjualan tunai. Faktur penjualan tunai diisi oleh fungsi penjualan yang berfungsi sebagai pengantar pembayaran kepada fungsi kas dan sebagai dokumen sumber untuk pencatatan transaksi penjualan ke dalam jurnal penjualan. ${ }^{16}$

b. Pita Register Kas (Cash Register Tape). Penerimaan kas yang berasal dari hasil penjualan tunai sebaiknya dilakukan melalui kas register pada saat transaksi penjualan terjadi, untuk menjamin bahwa angka rupiah yang dimasukan melalui kas register sesuai dengan harga jual yang sesungguhnya. ${ }^{17}$ Menurut Mulyadi, dokumen ini dihasilkan oleh fungsi kas dengan cara mengoperasikan mesin register kas (cash register). ${ }^{18}$ Pita register kas ini merupakan bukti penerimaan kas yang dikeluarkan oleh fungsi kas dan merupakan dokumen pendukung faktur penjualan tunai yang dicatat dalam jumlah penjualan. ${ }^{19}$ Menurut Jerry J. Weygandt, dkk, berpendapat bahwa pita mesin kas memberikan bukti penjualan tunai. ${ }^{20}$

c. Credit Card Sales Slip. Dokumen ini dicetak oleh credit card center bank yang menerbitkan kartu kredit dan diserahkan kepada perusahaan yang menjadi nasabah kartu kredit. Bagi perusahaan yang menjual barang atau jasa, dokumen ini diisi oleh fungsi kas dan berfungsi sebagai alat untuk menagih uang tunai dari bank yang mengeluarkan kartu kredit untuk transaksi penjualan yang telah dilakukan kepada pemegang kartu kredit.

d. Bill of Lading. Dokumen ini merupakan dokumen sumber tanda pengiriman untuk kegiatan bisnis mengirim pesanan. Menurut Mulyadi, dokumen ini merupakan bukti penyerahan barang dari perusahaan penjualan barang kepada perusahaan angkutan umum. ${ }^{21}$

e. Faktur Penjualan COD. Dokumen ini digunakan untuk merekam penjualan COD. Tembusan faktur penjualan COD digunakan oleh perusahaan untuk menagih kas yang harus dibayar oleh pelanggan pada saat penyerahan barang yang dipesan oleh pelanggan.

f. Bukti Setor Bank. Dokumen ini dibuat oleh fungsi kas sebagai bukti penyetoran kas ke bank. Bukti setor bank diserahkan oleh fungsi kas kepada fungsi akuntansi dan dipakai oleh fungsi akuntansi sebagai dokumen sumber untuk pencatatan transaksi penerimaan kas dari penjualan tunai ke dalam jurnal penerimaan kas.

g. Rekap Harga Pokok Penjualan. Dokumen ini digunakan oleh fungsi akuntansi untuk meringkas harga pokok produksi yang dijual selama satu periode. Dokumen ini digunakan oleh fungsi akuntansi sebagai dokumen pendukung bagi pembuatan bukti memorial untuk mencatat harga pokok produk yang dijual.

\section{Sistem Bagi Hasil}

Menurut Muhammad, bagi hasil diartikan sebagai distribusi beberapa bagian dari laba pada para pegawai dari suatu perusahaan. ${ }^{22}$ Adapun bahan pertimbangan dalam penetapan nisbah bagi hasil menurut Karim adalah meliputi referensi tingkat keuntungan dan perkiraan tingkat

15 Krismiaji, Op. Cit. 38

16 Mulyadi, Loc. Cit

17 Jusup Al Haryono, Dasar-Dasar Akuntansi jilid 2, Yogjakarta; STIE YKPN, 2001, hal.8

18 Mulyadi, Loc. Cit.

19 Ibid

20 Jerry Weygandt J., dkk., Op. Cit., hal. 268

21 Mulyadi, Op. Cit., hal. 465

22 Muhammad, Manajemen Pembiayaan Mudharabah di Bank Syariah. Jakarta: Rajawali Press, 2008, hal. 101 
keuntungan bisnis yang dibiayai. ${ }^{23}$ Menurut Tarsidin, ada dua faktor yang mempengaruhi besarnya nominal bagi hasil, yaitu profit dan skema bagi hasil. ${ }^{24}$

\section{Sistem Bunga}

Menurut Kasmir, bunga diartikan sebagai balas jasa yang diberikan oleh bank yang berdasarkan prinsip konvensional kepada nasabah yang membeli atau menjual produknya. ${ }^{25}$ Dalam kegiatan konvensional sehari-hari, ada dua macam bunga yang diberikan kepada nasabahnya, yaitu bunga simpanan dan bunga pinjaman. Bunga simpanan merupakan pendapatan yang diberikan pihak bank kepada nasabah yang telah menabung di bank sebagai bentuk balas jasa. Sedangkan bunga pinjaman merupakan bunga yang dibebankan kepada para peminjam dana (debitur) karena meminjam uang di bank. Ada tiga metode pembebanan bunga, yaitu flate rate, sliding rate, dan floating rate. Flate rate merupakan pembebanan bunga setiap bulan tetap dari jumlah pinjamannya. Demikian pula pembayaran pokok pinjaman juga tetap setiap bulannya, sehingga angsuran setiap bulan juga selalu sama sampai kredit tersebut lunas. Berbeda dengan sliding rate. Sliding rate merupakan pembebanan bunga setiap bulan yang jumlahnya dhitung dari sisa pinjamannya, sehingga jumlah yang dibayar oleh nasabah selalu menurun setiap bulannya. Metode pembanan bunga yang ketiga adalah floating rate. Floating rate menetapkan besar kecilnya bunga kredit yang dikaitkan dengan bunga yang berlaku di pasar uang, sehingga bunga yang dibayar setiap bulan tergantung pada bunga pasar uang tersebut.

\section{Pembiayaan Mudharabah}

Menurut UU No. 10 tahun 1998, pembiayaan berdasarkan prinsip syari'ah adalah penyediaan dana atau tagihan berdasarkan persetujuan atau kesepakatan antara bank dengan pihak lain yang mewajibkan pihak yang dibiayai untuk uang tersebut setelah jangka waktu tertentu dengan imbalan bagi hasil. Menurut Rivai, dalam melakukan analisis penerima pembiyaan, lembaga keuangan harus mempertimbangkan persyaratan yang dikenal dengan 6C, yaitu character, capital, capacity, collateral, condition, dan constrains. ${ }^{26}$

Analisis character mengandung makna analisis terhadap keadaan watak atau sifat nasabah. Analisis capital adalah analisis yang dilakukan pada jumlah modal yang dimiliki oleh calon penerima pembiayaan. Analisis capacity lebih menganalisis bagaimana kemampuan yang dimiliki calon penerima pembiayaan dalam membayar hutang jangka pendek. Sedangkan analisis collateral adalah analisis yang dilakukan terhadap jaminan yang dimiliki oleh calon penerima pembiyaan. Analisis yang lain adalah analisis condition, yang mana dalam analisis condition ini lebih menganalisis kondisi politik, sosial, ekonomi dan budaya yang mempengaruhi keadaan perekonomian. Analisis yang terakhir yaitu analisis constrains yang merupakan analisis yang dilakukan pada hambatan apa saja yang tidak memungkinkan berjalannya bisnis yang akan dijalankan.

Karim menjelaskan bahwa mudharabah adalah bentuk kerjasama antara dua pihak atau lebih dimana pihak pemilik dana (shahibul maal) menyediakan seluruh modal, dan mempercayakan modal tersebut kepada pengelola dana (mudharib) dengan suatu penjanjian pembagian keuntungan. ${ }^{27}$ Fatwa DSN-MUI No. 07/DSN-MUI/IV/2000 menjelaskan bahwa jangka waktu pengembalian dana ditentukan berdasarkan kesepakatan kedua belah pihak. Fatwa ini mengandung arti pula bahwa setiap kesepakatan seharusnya bersifat fleksibel dan tidak kaku.

23 Adiwarman A. Karim.Bank Islam Analisis Fiqih dan Keuangan. Jakarta: PT Raja Grafindo Persada. 2004. hal. 286

24 Tarsidin. Bagi Hasil, Konsep dan Analisis. Jakarta: Lembaga Penerbit FEUL. 2010

25 Kasmir. Dasar-dasar perbankan. Jakarta: Rajawali Press. 2002

26 Rivai, V\& Veithzal, A.P. Islamic Financial Management. Jakarta: Raja Grafindo Persada.2008

27 Adiwarman A. Karim. Loc. Cit. 


\section{METODOLOGI}

Laporan ini ditulis berdasarkan tugas magang yang dilakukan peneliti pada BMT KI Ageng Pandanaran Semarang selama satu bulan. BMT ini terletak di kelurahan Mugassari, Semarang. BMT Ki Ageng Pandanaran Semarang mulai beroperasi sejak 1 Oktober 1998 dan disahkan oleh Menteri urusan koperasi dan usaha kecil menengah Republik Indonesia sejak 7 Mei 2003. Dari tahun ke tahun BMT Ki Ageng Pandanaran Semarang mengalami perkembangan yang signifikan dan menggembirakan.

Penelitian ini adalah jenis penelitian kualitatif dengan lima sampel, sehingga pembaca harus berhati-hati dalam membaca dan menyimpulkan penelitian ini. Sementara pencarian data dilakukan dengan menggunakan metode wawancara dengan pihak-pihak yang terkait pembiayaan mudharabah dan penerimaan kas, antara lain karyawan BMT Ki Ageng Pandanaran Semarang dan nasabah yang melakukan pembiayaan. Wawancara dilakukan dengan dua orang pegawai BMT Ki Ageng Pandanaran Semarang dan tiga nasabah.

\section{HASIL DAN PEMBAHASAN}

Dari hasil wawancara tersebut diperoleh hasil penelitian yang dijelaskan di bawah ini. Hasil penelitian dibahas dan dikelompokkan dalam empat sub pembahasan, yaitu; Sistem Pengendalian Intern Penerimaan Kas, Sumber Penerimaan Kas, Komparasi Antara Sistem Bagi Hasil dan Sistem Bunga, dan Pembiayaan Mudharabah.

\section{Sistem Pengendalian Intern Penerimaan Kas}

Pengamatan penelitian menemukan bahwa sistem pengendalian intern penerimaan kas pada BMT Ki Ageng Pandanaran Semarang belum cukup baik dan belum sesuai prinsip pengendalian intern kas yang ada. Fungsi yang terkait dengan sistem pengendalian intern penerimaan kas pada BMT Ki Ageng Pandanaran Semarang meliputi teller, bagian pembukuan, dan marketing. Dalam hal ini, teller dan bagian pembukuan telah bekerja dengan baik dan sesuai dengan prinsip pengendalian intern kas yang ada. Namun fungsi marketing belum bekerja sesuai prinsip yang ada. Hal ini dikarenakan adanya perangkapan jabatan yang dilakukan oleh bagian marketing. Selain menjalankan fungsinya, marketing juga mempunyai tanggung jawab untuk mengelola usaha sembako. Hal ini jelas tidak sesuai prinsip pengendalian intern kas yang ada.

Sementara dokumen yang digunakan dalam proses penerimaan kas pada BMT Ki Ageng Pandanaran Semarang sudah baik dan sesuai dengan prosedur yang berlaku. Hal ini dikarenakan dokumen-dokumen yang digunakan BMT Ki Ageng Pandanaran Semarang telah sesuai dengan kebutuhan dalam proses penerimaan kas pada BMT, yang meliputi slip setoran dan buku simpanan. Slip setoran merupakan bukti bahwa telah terjadi penyetoran atau penerimaan uang dari nasabah kepada BMT. Sementara buku simpanan merupakan media penulisan jumlah tabungan yang telah ditabung oleh nasabah.

\section{Sumber Penerimaan Kas}

Pengamatan penelitian menemukan bahwa penerimaan kas pada BMT Ki Ageng Pandanaran Semarang diperoleh dari berbagai sumber berikut;

a. Pendapatan administrasi buku simpanan. Pendapatan administrasi buku simpanan merupakan pendapatan yang diperoleh dari pembayaran nasabah yang ingin menyimpan di BMT Ki Ageng Pandanaran Semarang. Setiap nasabah yang ingin menyimpan di BMT Ki Ageng Pandanaran Semarang diharuskan membuat buku simpanan dan dikenai biaya administrasi buku simpanan sebesar Rp 3000,00.

b. Pendapatan bagi hasil pembiayaan. Pendapatan bagi hasil pembiayaan merupakan pendapatan yang diperoleh dari bagi hasil yang dibayar oleh nasabah sesuai akad pembiayaan yang ditentukan dalam akad pembiayaan yang disepakati antara pihak BMT 
Ki Ageng Pandanaran Semarang dengan nasabah. Pada awalnya sistem bagi hasil ini berdasarkan nisbah 35\%:65\%. Namun beberapa tahun kemudian, nisbah ini berubah menjadi 25\%:75\%. Seiring berjalannya waktu, pihak masyarakat merasa sangat dibantu oleh pihak BMT Ki Ageng Pandanaran Semarang. Akhirnya terjadi kesepakatan antara pihak BMT Ki Ageng Pandanaran Semarang dengan pihak nasabah dengan nisbah sebesar $35 \%: 65 \%$. Namun, sistem bagi hasil ini ternyata mempunyai kelemahan. Kelemahannya yaitu para nasabah yang melakukan pembiayaan ternyata tidak bisa terbuka masalah pendapatan mereka. Akhirnya disepakati bahwa pendapatan bagi hasil di BMT Ki Ageng Pandanaran Semarang adalah sebesar 2\% dari jumlah pembiayaan.

c. Pendapatan administrasi pembiayaan. Pendapatan administrasi pembiayaan adalah pendapatan yang diperolah dari pembayaran administrasi oleh pihak nasabah yang telah mendapatkan pembiayaan di BMT Ki Ageng Pandanaran Semarang. Jumlah pendapatan administrasi pembiayaan adalah sebesar $2,25 \%$ dari jumlah pembiayaan.

d. Pendapatan bagi hasil bank. Pendapatan bagi hasil bank merupakan pendapatan yang diperoleh pihak BMT Ki Ageng Pandanaran Semarang dari bagi hasil bank. Beberapa bank yang bekerjasama dengan BMT Ki Ageng Pandanaran Semarang adalah Bank Syari'ah Mandiri, Bank Syari'ah Bukopin, dan lain-lain.

e. Pendapatan lain-lain. Pendapatan lain-lain adalah pendapatan yang diperoleh dari luar operasional koperasi, seperti pendapatan yang berasal dari pembayaran listrik, telepon, dan PDAM.

f. Secara pengamatan dan hasil wawancara disimpulkan bahwa sumber penerimaan kas yang diperoleh pihak BMT Ki Ageng Pandanaran Semarang adalah wajar dan sesuai dengan prinsip pengendalian intern kas yang ada, yaitu meliputi pendapatan administrasi buku simpanan, pendapatan bagi hasil pembiayaan, pendapatan administrasi pembiayaan, pendapatan bagi hasil bank, dan pendapatan lain-lain.

Namun demikian ada beberapa praktek yang tidak sesuai dengan prinsip syari'ah, khususnya terkait sumber penerimaan kas yang diperoleh pihak BMT Ki Ageng Pandanaran Semarang. Sumber penerimaan kas yang bermasalah adalah pendapatan bagi hasil pembiayaan dan pendapatan administrasi pembiayaan. BMT Ki Ageng Pandanaran Semarang adalah sebuah koperasi simpan pinjam dan pembiayaan syari'ah, maka sistem yang berjalan seharusnya menggunakan sitem bagi hasil. Namun yang terjadi adalah pendapatan bagi hasil pembiayaan dan pendapatan administrasi pembiayaan tidak menggunakan prinsip bagi hasil, karena untuk dua jenis pendapatan tersebut telah menetapkan prosentase didepan. Dan ini menyalahi prinsip syari'ah.

\section{Komparasi Antara Sistem Bagi Hasil dan Sistem Bunga}

Temuan penelitian diatas menyebutkan bahwa praktek BMT Ki Ageng Pandanaran Semarang terkait dengan sumber penerimaan kas dari pembiayaan mudharabah tidak sesuai dengan prinsip syari'ah. Meskipun pada dasarnya bank syari'ah dan bank konvensional memiliki fungsi yang sama, yaitu bahwa kedua-duanya merupakan lembaga penghimpun dana dan penyalur dana dari masyarakat. Namun keduanya memiliki perbedaan yang terletak pada sistem yang digunakan. Bank syari'ah dalam operasionalnya menggunakan sistem bagi hasil sedangkan bank konvensional menggunakan sistem bunga, sebagaimana dirangkum dalam tabel 1 di bawah ini. 
Tabel 1: Perbedaan Sistem Bunga dan Sistem Bagi Hasil ${ }^{28}$

\begin{tabular}{ll}
\hline \multicolumn{1}{c}{ BUNGA } & \multicolumn{1}{c}{ BAGI HASIL } \\
\hline $\begin{array}{l}\text { Penentuan bunga dibuat pada waktu akad dengan } \\
\text { asumsi harus selalu untung. }\end{array}$ & $\begin{array}{l}\text { Penentuan besarnya rasio/nisbah bagi hasil } \\
\text { dibuat pada waktu akad dengan berpedoman } \\
\text { pada kemungkinan untung dan rugi. }\end{array}$ \\
$\begin{array}{l}\text { Besarnya prosentase berdasarkan jumlah uang } \\
\text { (modal) yang dipinjamkan. }\end{array}$ & $\begin{array}{l}\text { Besarnya rasio bagi hasil berdasarkan jumlah } \\
\text { keuntungan yang diperoleh. }\end{array}$ \\
$\begin{array}{l}\text { Pembayaran bunga tetap seperti yang dijanjikan } \\
\text { tanpa pertimbangan apakah proyek yang } \\
\text { dijalankan oleh pihak nasabah untung atau rugi. }\end{array}$ & $\begin{array}{l}\text { yang dijalankan. Bila usaha merugi, kerugian } \\
\text { akan ditanggung bersama oleh kedua belah } \\
\text { pihak berdasarkan porsi masing-masing. }\end{array}$ \\
$\begin{array}{l}\text { Jumlah pembayaran bunga tidak meningkat } \\
\text { sekalipun jumlah keuntungan berlipat atau } \\
\text { ekonomi dengan "booming” }\end{array}$ & $\begin{array}{l}\text { Jumlah pembagian laba meningkat sesuai } \\
\text { dengan peningkatan jumlah pendapatan. }\end{array}$ \\
$\begin{array}{l}\text { Eksistensi bunga diragukan oleh semua agama, } \\
\text { termasuk Islam. }\end{array}$ & \begin{tabular}{l} 
Tidak ada yang meragukan keabsahan bagi hasil. \\
\hline
\end{tabular}
\end{tabular}

\section{Pembiayaan Mudharabah}

Dalam perjanjian perikatan akad mudharabah, pihak BMT Ki Ageng Pandanaran Semarang kurang fleksibel dalam permodalannya, seperti yang disampaikan oleh salah satu nasabah BMT Ki Ageng Pandanaran Semarang yang bernama Ibu Endang. "Saya tidak diberikan kesempatan untuk tawar menawar bagaimana cara mengembalikan modalnya mas. Setiap bulan kita diharuskan membayar angsuran yang ditetapkan BMT." Bahkan dalam pembiyaan mudharabah, pihak BMT Ki Ageng Pandanaran Semarang menetapkan prosentase di depan yang mana hal tersebut kurang sesuai dengan prinsip syari'ah. BMT Ki Ageng Pandanaran Semarang mempunyai konsep yang sama antara nasabah yang satu dengan nasabah yang lain dengan kebijakan pengembalian modal secara angsur setiap bulannya. Hal ini menjadikan kurang efektinya pembiayaan mudharabah dalam menghasilkan penerimaan kas bagi BMT. Nasabah BMT Ki Ageng Pandanaran Semarang terdiri atas beberapa golongan usaha yang berbeda-beda. Setiap nasabah mempunyai agenda kerja yang berbeda-beda baik dari segi waktu lamanya produksi, pemasaran, ataupun pendapatannya. Hal ini menjadikan para nasabah merasa terbebani ketika usahanya belum mencapai target sedangkan meraka harus membayar kewajibannya. Hal ini juga yang membuat minat nasabah dalam melakukan pembiyaan mudharabah menjadi menurun, sehingga penerimaan kas yang diperoleh BMT Ki Ageng Pandanaran Semarang juga menurun.

\section{SIMPULAN DAN SARAN}

Pembiayaan mudharabah merupakan salah satu sumber penerimaan kas bagi BMT Ki Ageng Pandanaran Semarang melalui pendapatan bagi hasil pembiyaan. Namun masih sedikit nasabah yang menggunakan fasilitas pembiyaan mudharabah pada BMT Ki Ageng Pandanaran Semarang. Hal itu dikarenakan kurang fleksibelnya BMT Ki Ageng Pandanaran Semarang dalam prosedur pembiyaan mudharabah. Nasabah cenderung takut apabila usaha mereka belum mencapai target yang diinginkan padahal mereka harus membayar kewajibannya.

Penerapan prosedur yang fleksibel dapat menjadi solusi agar minat nasabah untuk menggunakan fasilitas pembiayaan menjadi naik. Dengan begitu, penerimaan kas yang berasal dari pendapatan bagi hasil pembiyaan juga naik, sehingga penerimaan kas BMT Ki Ageng Pandanaran Semarang juga akan naik dan pada akhirnya visi, misi dan tujuan yang diinginkan BMT Ki Ageng Pandanaran Semarang dapat tercapai.

28 Z., Ali. Hukum Perbankan Syariah. Jakrta: Sinar Grafika. 2008 


\section{DAFTAR PUSTAKA}

Ali, Z. (2008). Hukum Perbankan Syariah. Jakrta: Sinar Grafika

Jusup, Al Haryono, (2001), Dasar-Dasar Akuntansi jilid 2, Yogjakarta: STIE YKPN

Karim, Adiwarman A. (2004). Bank Islam Analisis Fiqih dan Keuangan. Jakarta: PT Raja Grafindo Persada

Kasmir. (2002). Dasar-dasar perbankan. Jakarta: Rajawali Press

Krismiaji. (2005). Sistem Informasi Akuntansi. Yogyakarta: UPP AMP YKPN

Muhammad. (2008). Manajemen Pembiayaan Mudharabah di Bank Syariah. Jakarta: Rajawali Press

Mulyadi. (2001). Sistem Akuntansi. Jakarta: Salemba Empat

Rivai, V \& Veithzal, A.P. (2008). Islamic Financial Management. Jakarta: Raja Grafindo Persada Tarsidin. (2010). Bagi Hasil, Konsep dan Analisis. Jakarta: Lembaga Penerbit FEUL

Weygandt, Jerry J., dkk, , 2007, Accounting Principles Edisi Ketujuh, Jakarta; Salemba Empat

Widjajanto, Nugroho, 2001, Sistem Informasi Akuntansi, Jakarta; Erlangga 